\title{
AN AIRSPACE MODEL APLICABLE FOR AUTOMATIC FLIGHT ROUTE PLANNING INSIDE FREE ROUTE AIRSPACE
}

\begin{abstract}
The article is strongly related to the Single European Sky ATM Research (SESAR) project. The project's objective is the improvement of air transport above Europe 0 . Since Air Traffic Management (ATM) is involved to obtain more effective approach to air traffic flow managing activities, the concept of Flexible Use Airspace (FUA) has arisen in result. ATM is a quite developed aviation's subdomain, therefore currently existing airspace state has been described briefly in the article, referring to the presented solution concept. The notion of Free Route Airspace (FRA) airspace model defined in this article relies on mathematical description. The selected approach clarifies airspace as a set of squares or cubes that have volumes with appointed values due to certain conditions in the considered time (i.e. traffic flow or weather). The model has to ensure facilitation of flight route planning and warrant aircrafts separation towards flight safety assurance. The concept assumes that this airspace model will provide assistance for airspace user to select essential flight plan criteria, such as economy, time, etc. The path will be appointed according to personal preferences, based on the model from which further elaborated algorithm will evaluate situation.

The presented solution is a response to air traffic growth. Therefore it supports the SESAR project through research and development activities. The description proves that airspace model would create enhancement in flight planning for airspace users.
\end{abstract}

Keywords: transport, navigation, air transport, flight planning, flight safety

\section{Introduction}

The major goal of ATM is to provide high-performance of air traffic flows. The growing number of flight operations causes increasing density of air traffic flow that emerged in recent years. With increasing air transport commonness, the

${ }^{1}$ Grzegorz Drupka, Rzeszow University of Technology, e-mail: g.drupka@prz.edu.pl

2 Andrzej Majka, Rzeszow University of Technology, e-mail: andrzej.majka@prz.edu.pl

3 Autor do korespondencji/corresponding author: Tomasz Rogalski, Department of Avionics and Control Systems, Rzeszow University of Technology, tel.: 607973672, e-mail: orakl@ prz.edu.pl

${ }^{4}$ Leszek Trela, Rzeszow University of Technology, e-mail: 1trela@prz.edu.pl 
airspace demands reconfiguration. ATM focuses on both modernization of existing and development of new, more efficient approaches and instruments governing the air traffic. The European Organization for the Safety of Air Navigation (EUROCONTROL with headquarters in Brussels) is the unit involved in coordination of the framework of the Single European Sky ATM Research [1]. It synchronizes activities between ATM stakeholders, such as Air Navigation Service Providers (ANSP), research centers and airlines in the program the common goal of which is to achieve, due to air operations requirements, modern airspace structure. Some measures are carried out to provide high-performance of traffic - for instance by reducing route distances, fuel consumption etc. [2]. Therefore, the idea of Free Route Airspace (FRA) has suggested that the flight planning process is still an essential element in the air transport chain. SESAR stakeholders are quite involved in works to reach maximum airspace capacity, together with possibilities to make as well the flight paths as short as possible. Actually flight plan preparation process is a complicated and not transparent procedure to airspace users. Manual process, in fact, still remains supported by many technical means. For the convenience of airspace users and better usage of the possibilities FRA implies it is necessary to automate this procedure [3-5]. The article provides general FRA overview in comparison to the classical, network based airways structure. However, it focuses on an airspace model applicable to the automatic rout selection process in order to facilitate the entire flight planning process.

\section{The current structure of airspace}

Significant aviation growth has affected the search and implementation of different solutions for improvement due to the demands of ATM purposes. Established in year 1960, EUROCONTROL's mission is unification of air procedures within European sky. The organization is involved in numerous projects, the goal of which is to fulfill ATM mission by the Flexible Use of Airspace (FUA). That situation is seen as integration of Air Traffic Control (ATC) systems, causing to elaborate European Air Traffic Control Harmonization and Integration Program (EATCHIP). The priority is to ensure flight efficiency and economy together with safety enhancement by enhanced flight planning.

Currently the entire European airspace is divided into Flight Information Regions (FIR) which comprise Area Control Centres (ACCs). ACC have different shape (Fig. 1a) and are monitored by Air Traffic Control Officers (ATCOs). Terminal Maneuvering Area (TMA) and Controlled Traffic Region (CTR) are elements of aerodrome management that support traffic protection to and from airport. Polish airspace is formed by one FIR and nine ACCs.

Since the airspace refers to three dimensional space with regard to time, commonly exists flight level (FL) presented in the picture above (Fig. 1b). Regular cruise phase takes place between FL095 and FL460. Between FL195 and FL460 flights are performed with respect to Air Traffic Service (ATS) route network or 
FRA rules, depending on the specified airspace. To maintain flight planning activities more efficient the airspace consists of virtually constructed elements defined as sectors. Sectors jointed together into cluster have own specified volume. There is possible to not allow traffic during specified time interval in sectors or by certain airways (AWY). Sectors even support monitoring flights from past, creating facilitations to observe airspace efficiency.

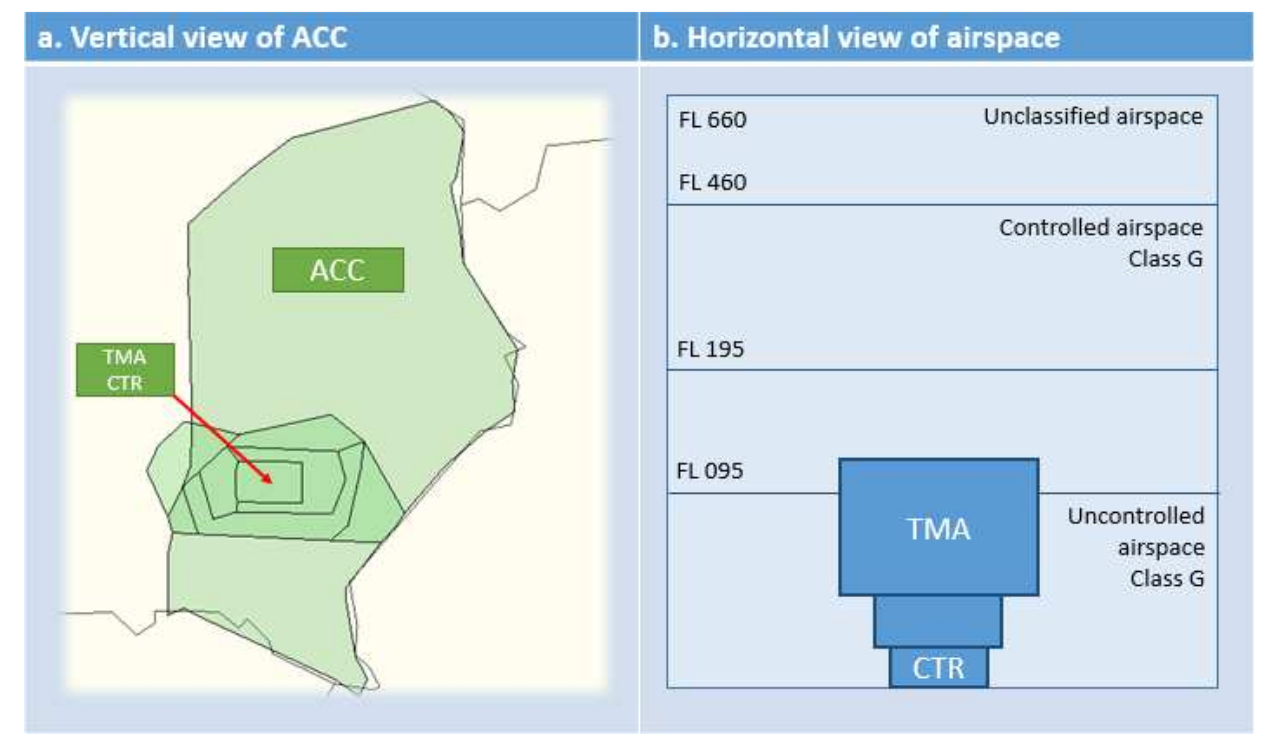

Fig. 1. Structure of the airspace in the vertical (a) and horizontal (b) view

Nowadays the entire structure has a static character but some works incline towards structure with dynamically modified number, shapes and location of some of its components [6]. The preparation process of a flight plan demands operator/airspace user to provide EUROCONTROL with many required operational data. Within wording data, there is information about the place of arrival and departure, routes, waypoints the flight will be executed through and time. It is obligatory for airspace user to familiarize with airspace availability well before the declared time of operation. The user is obligated to be familiarized with Aeronautical Information Service (AIS), Aeronautical Information Publication (AIP) and Notice to Airman (NOTAM). Unfortunately, nowadays it is impossible to obtain information whether other airspace users have already prepared some flight plan in the same airspace location and the same time. Moreover if an airspace user could obtain access to information about flights potentially interfering with its flight plan immediately after a query, then it would be possible to make corrections towards avoiding potential conflicts and personal preferences.

The EUROCONTROL role now is limited to acceptance or rejection of the submitted flight plan. One of the biggest weaknesses of the current system is that 
airspace users do not get any detail feedback pointing reasons the flight plan is rejected. They are forced to next iterations until is successful. The concept of entire process modification $[3,7]$ significantly reduces the role of the airspace user. Moving more responsibility toward automatic systems operated by EUROCONTROL. EUROCONTROL's member states have declared to replace the ATS route network with FRA. However this process takes place gradually. Picture (Fig. 2) presents the difference between FRA (BUDAPEST FIR) and classical airspace where ATS route network (BRATISLAVA FIR) still finds an application. In both cases the waypoints (WTP) linked with each other create flight paths structure, but FRA provides the possibility to use connections between WTPs specified by user, with no reference to ATS routes. The FRA enables to use Entry (E) and Exit (X) WTP in order to obtain the shortest possible connection inside FIR. The Route Availability Document (RAD) chart shows the possibility to use en-route directs (DCTs) and is updated with Aeronautical Information and Control (AIRAC) cycle every 28 days.

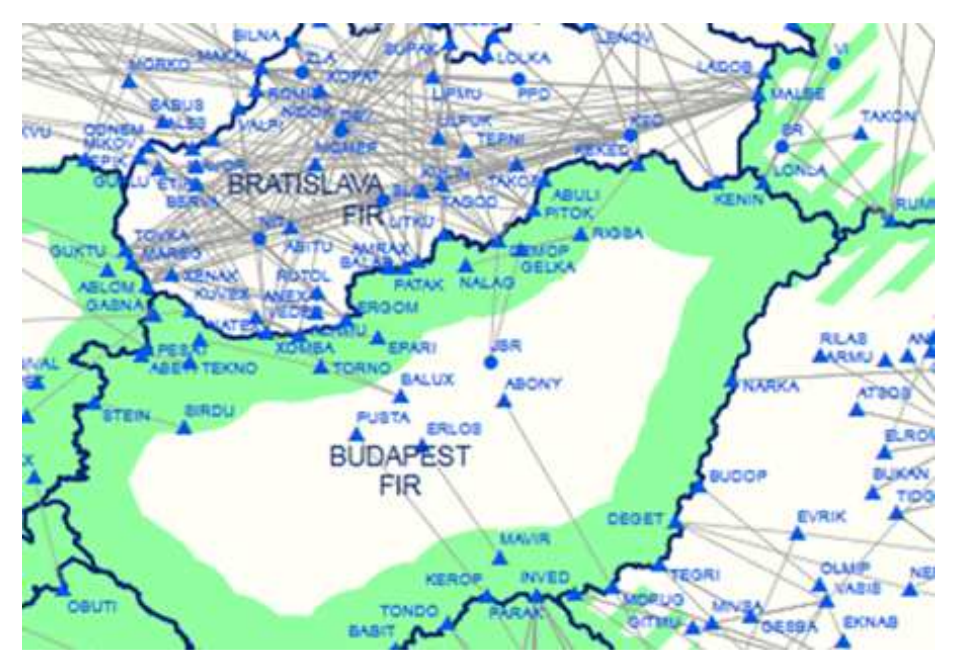

Fig. 2. Fragment of RAD 1707 chart that presents available DCT's, Eurocontrol.int, June $22^{\text {nd }} 2017$

EUROCONTROL develops solutions that aim toward the most possible smooth and safe management of air traffic. The organization is involved in the Single European Sky ATM Research (SESAR) programme. Since SESAR master plan is focused on introduction of FUA, the FRA has become the crucial solution in flight planning. The concept assumes performing flights from entry to exit points by the shortest path. In the most general form, from departure to arrival place with no reference to the ATS Route Network but freely via defined E and $\mathrm{X}$ points. Intermediate points are used only if it is absolutely demanded by some factors. FRA has actually not been announced by all member states. According to 
data, performing flights using the ATS route network is less effective if massive traffic is considered, although modern navigation systems enable reduction of separation distances between airplanes. Traffic forecasts include a few fields such as routes efficiency, sectors capacity, and vertical and horizontal separation possibilities supporting ATS solving conflicts in real time but is still overloaded with work.

\section{Notion of Automatic Flight Route Planning}

To fully utilize opportunities FRA provides, ATM should be provided with new facilities supporting Automatic Flight Route Planning procedures [3, 7]. The greatest advantages can be acquired if airspace user would declare departure and arrival points in the preferred operation time restrictions only. The system searches and proposes suggestion(s) of route(s) according to flight character, time, user preferred criteria, i.e. economy etc. User activity is to be reduced to selecting and confirming the flight plan only. The flight route is calculated on the basics of input data available to the system. The statement „merged sources data” means:

- airspace availability - according to volume, excluded sectors, etc.,

- traffic volume,

- weather conditions and current flight relative forecasts,

- established optimization criteria,

- aircraft type and exploiting characteristics,

- other information important to take into account.

In the most general case data (target solution for the future) the airspace user has to define departure and arrival points and departure time only.

A flight route planning algorithm applicable to FRA, running within systems and automatically planning flights requires application of an appropriate mathematical airspace model. The presented methods comes from the graph theory [3, 7] however requires the airspace model enabling efficient transition from the homogenous, continuous form of the proceeded airspace to the discrete one. The point is: there are not any marked characteristic points in the proceeded airspace. All waypoints, straight or curve legs are the result of calculation. The algorithm works in humongous space producing the flight route as a result. It takes into account certain assumptions considering Airspace Model complexity:

- Assumption 1: The model enables to map the selected humongous space by the graph.

- Assumption 2: The model can turn humongous space into discrete one with virtual route waypoints located at network vertexes and route legs located at graph legs.

- Assumption 3: It is accepted that some specific areas are lost and excluded from calculation because of model fidelity level. 
According to assumptions 1-3 that constitute the graph-network approach, the entire airspace is mapped by the graph (Fig. 3). Since the selected piece of airspace is mapped by the graph with vertex located at centers of unity cells the graph-network theory is applied to find the critical path [8] with the usage of typical algorithms (i.e. Dijkstra's algorithm). The obtained critical graph's path is recognized as a desired optimal flight route. A criterion applicable for optimization process, defining value of each path is formulated in terms of parameters assigned to graphs edges $[6,9]$.

$$
\boldsymbol{G}=\langle\boldsymbol{V}, \boldsymbol{E}, \boldsymbol{W}\rangle
$$

where: $\mathrm{G}$ - the critical path,

$\mathrm{V}$ - set of graph's nodes; $V=\left\{v_{1}, v_{2}, \ldots, v_{n}\right\}, v$ - node of the graph,

$E$ - set of graph's edges; $E=\left\{e_{1}, e_{2}, \ldots, e_{n}\right\}, e$-edge of the graph.

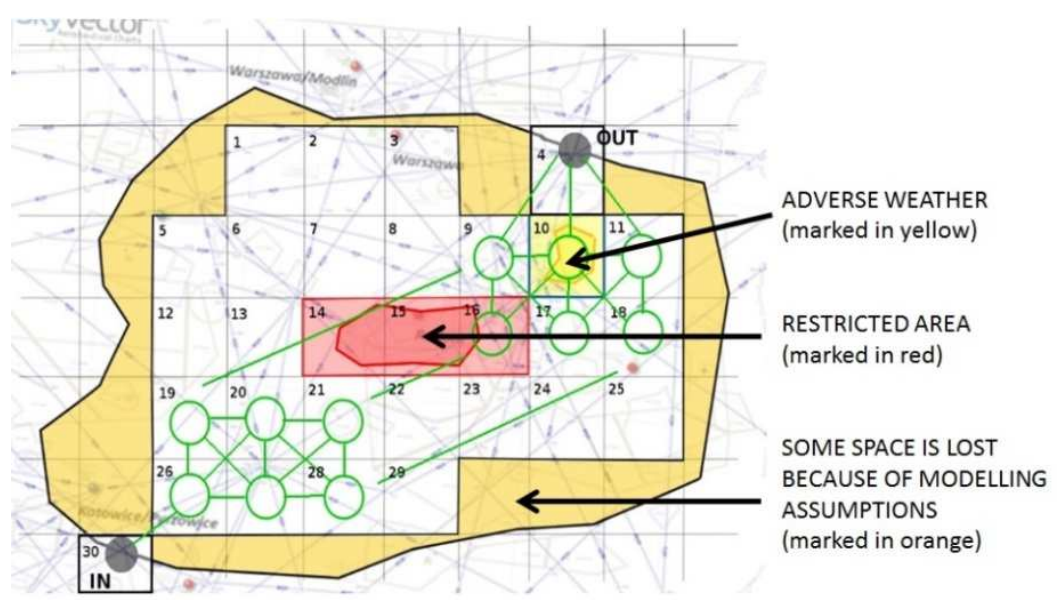

Fig. 3. An example of airspace covered by the virtual FRA and mapped by the graph

The airspace model considered later in this paper is composed of clusters of unity cells. All of them are located totally inside the airspace. Graph nodes are located at their centers, excluding nodes representing airspace entry and exit points. A path calculation process is to be executed by the defined $[3,7]$ algorithm. The algorithm takes into account the accepted optimization method which is going to be a subject of further investigations that comprises a part of another project. If there are no obstacles on the flight path, then in the most general case settled take-off (IN) and landing (OUT) spots would be linked together in a way regarding selected optimization criteria. If there are any obstacles on the shortest selected trajectory then the system should search an alternative route between selected points. 
The concept assumes the model of space is composed of cubes. That shape enables to define spatial orientation that is simplified and reasonable for the research attempts, certainly at the initial research level. Different shapes are not excluded from further studies, while seeking the satisfactory final result. The article presents 2D space example only, however it is crucial to find out appropriate contour character and the applicable size in 3D. However let us reduce investigations to 2D for the initial research phase. In such case a set of squares models the airspace. Squares fill the FRA space tightly and as completely as it is physically possible. Every square represents the space by spatial orientation through geographical coordinates combined with height above the geoid. Its bottom is parallel to the Earth's surface (assumption: dimensions of the squares allow for such simplification), beside position and orientation, square has assigned fundamental, in the presenting sense, set of parameters. The picture (Fig. 4) presents a target 3D concept, where green cubes indicate available space, whereas blue ones are excluded from use by different reasons (i.e. overflow, traffic density, weather conditions etc.). If air traffic density is considered as one of the parameters the model can support the algorithm solving potential conflicts already at flight planning phase. For example, since at the same time two planes have planned route via the same cube, the algorithm separates trajectories by assigning alternative flight parameters to one of them. Separation shall be executed at different surfaces such as flight levels, geographical coordinates or time. To visualize airspace availability, blue cubes show airspace volume excluded from flight planning in certain time. It causes that the algorithm, when searching available cells may assign a path only due to adopted criteria (the cells availability in this case). If user preferred criteria for seeking alternative flight plan are established, then eventual conflict would be discharged though delay in take-off time or on cruise phase.

Fig. 4. The basic example of FRA in 3D concept (EUROCONTROL's NEST software)

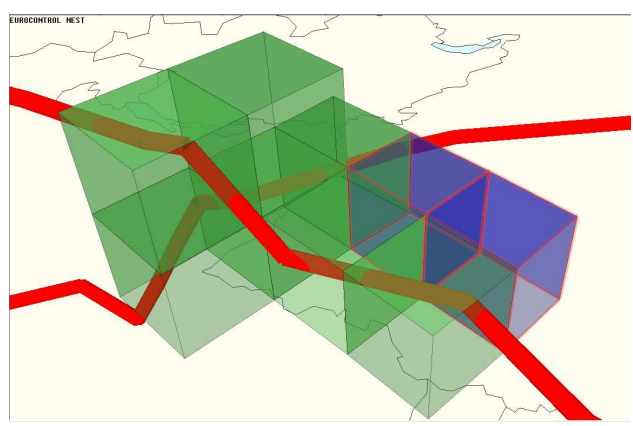

Calculation is based on specific set of parameters assigned to cubes, with graph vertexes located in centers. At this stage only limited set of parameters is considered:

- airspace availability,

- airspace load, 
- approximately cruise time via cell,

- weather conditions,

- admissible differences between entry and exit time,

- other significant records - data to be defined during further research. It is going to be expanded with new ones during next steps of research.

If the presumed airspace is modeled by the cluster of unity cubes, then A vector composed of $X$ vectors that represent the entire considered FRA (Fig. 5). Then unity cubes are defined by its components - vectors $X_{\mathrm{i}}$ see eq. (2), (3). To any vector $X_{i}$ vertex $v_{i}$ is assigned in its center.

$$
\mathrm{A}=\left[\begin{array}{c}
X_{1} \\
\ldots \\
X_{n}
\end{array}\right]
$$

where: A - Vector representing the entire FRA,

$n-$ global number of cells.

When every single $\mathrm{X}$-cell could be described like below:

$$
\mathrm{X}=\left[a_{1}, a_{2}, a_{3}, \ldots, a_{m}\right],
$$

where: $a_{m}$ - record containing data values representing specific airspace parameters, i.e. volume, weather, etc., $m$ - number of considered parameters.

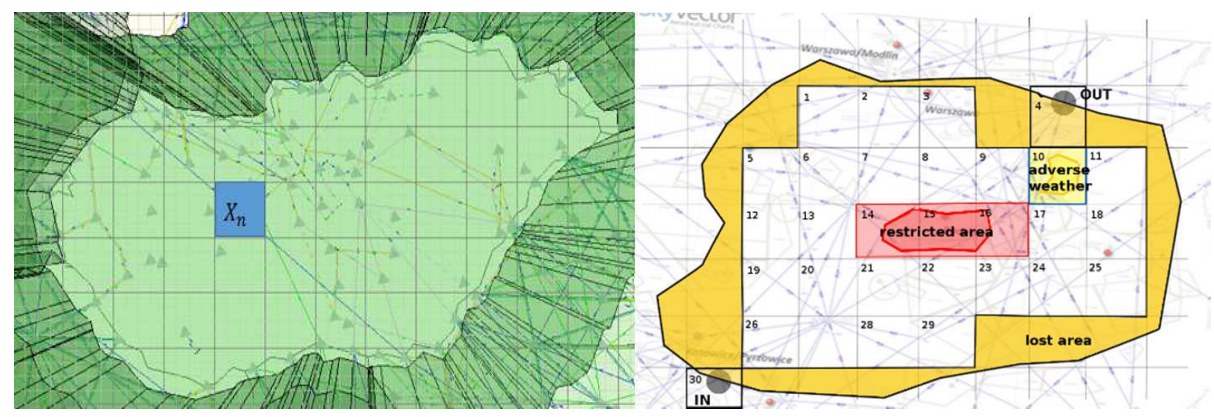

Fig. 5. The example of the basis space, in 2D: a) referring to real airspace, b) virtual space

In the case of simplest 2D squares, having the same size, assembling together determines entire analyzed space. Every cell has specification with reference to individual conditions and contains specific data saved into $\mathrm{X}$, while $\mathrm{X}$ is the record of parameters. Vector $\mathrm{X}$ describes crucial information, in the way that the table below presents. 
Table 1. Interpretation of vectors

\begin{tabular}{|c|c|}
\hline $\mathrm{X}=\left[a_{1}, a_{2}, a_{3}, \ldots, a_{n}\right]$ & Description of vector's interpretation \\
\hline$a_{1}$ & $\begin{array}{l}\text { Individual ID number, i.e. in cell: } \\
X_{1}=\left[a_{1}=1, \ldots\right] ; X_{2}=\left[a_{1}=2, \ldots\right] \text { (Fig. } 4 \text { ) } \\
\text { That number corresponds to vertex number } v_{i} \text { from graph G, } \\
\text { i.e. for vector } X_{1} \text {, record containing data } a_{1}=v_{1}\end{array}$ \\
\hline$a_{2}$ & $\begin{array}{l}\text { Record of contiguous cells numbers, i.e. once established, describing } \\
\text { method shall be used to every bloc i.e. clockwise. } \\
\text { a }_{2}=\text { [cell's above ID, right up cell's ID, right cell's ID ...] } \\
0 \text { (zero) - indicate no cell at this vicinity }\end{array}$ \\
\hline$a_{3}$ & $\begin{array}{l}\text { Distance to contiguous cells in order of IDs defined at a2 parameter. } \\
\text { Depends directly on cell's size and shape. } \\
\text { If cells are recognized as identical rectangles with edge length a then } \\
\text { distances are respectively } a \text { and } a^{*} \sqrt{2} \text {, depending on location of the } \\
\text { surrounding cells. }\end{array}$ \\
\hline$a_{4}$ & $\begin{array}{l}\text { Cell center's geographical coordinates. } \\
\mathrm{a}_{4}=\text { (latitude, longitude, height above geoid for 3D models) }\end{array}$ \\
\hline$a_{5}$ & $\begin{array}{l}\text { Vector containing cell airspace's availability in selected time intervals, } \\
\text { i.e. n-elementary vector, where every n-element contains information } \\
\text { about availability ( } 1) \text { or unavailability }(0) \text { within every defined time } \\
\text { step, i.e. } 20 \text { minutes. For safety reasons because of delays some ad- } \\
\text { vance to schedule IN time, time slots also should be considered. } \\
\text { as }=[1 \text { - the second time slot before, } 1-\text { last time gap before, } 1-\text { sche- } \\
\text { duled enter into airspace, } 0-\text { the first time gap afterwards, } 1-\text { the } \\
\text { second time gap afterwards, } 1-\text { the third time gap afterwards,..., } \\
1-\text { n-time gap afterwards }]\end{array}$ \\
\hline$a_{6}$ & Wind direction and velocity, i.e. $\mathrm{A}_{6}=($ direction, velocity $)$ \\
\hline$a_{7}$ & $\begin{array}{l}\text { Predictable traffic density in time interval, like a4 } \\
\left(\mathrm{T}=\frac{F_{c}}{V}\right) \\
\mathrm{T}-\text { cell availability in airspace model, } \\
F_{c} \text { - flight count within } 20 \text { minutes interval, } \\
\mathrm{C}-\text { cell's capability. } \\
* \text { available means that initial flights count to block volume ratio is less } \\
\text { than } 1(\mathrm{~A}<1) \text {. }\end{array}$ \\
\hline$a_{8}$ & $\begin{array}{l}\text { Different information crucial for FRA model to be defined in further } \\
\text { work if necessary. }\end{array}$ \\
\hline
\end{tabular}

In consequence, therefore, every single $X_{i}$ in global dataset holds essential information for flight planning. It is important, for further research, to find the method to reach most efficiency and accuracy. Accuracy is important to obtain adequate separation minimum to avoid conflicts. Dividing global space into the smallest possible cells due to space's accuracy would be profitable but has disadvantages. Great cells number demands longer evaluation time according to space complexity. First accuracy issue appears when a boundary divides the space into 
two sub-spaces: available and inaccessible, sharing single cell at two different areas. Therefore the unit box has been used. It means that to ensure safety, if any square does not fulfil assumptions then flight plan shall be not performed via it. Only cells that lay entirely inside accessible area will be taken under consideration. That applied model would exclude particular areas, but it guarantees flight safety. The second accuracy issue appears while a flight does not cross the cell's center, i.e. FRA entry or FRA exit.

According to assumptions included in chapter 3.1 the airspace model created that way shall be examined. Examination is based on using certain flight samples. Different additional principles, such as extra traffic, have been skipped. The algorithm optimization criteria are to find the shortest possible route due to adopted and described idea. No FL changes have been adopted for current example, therefore the route visible in the picture is performed at the same altitude all the time.

As it has been shown in the picture (Fig. 6), flight is performed between cells $21^{\text {st }}$ and $3^{\text {rd }}$. FRA entry and exit points are outside the marked area however they shall be taken into consideration. Adjacent cells, which are not located in FRA entirely do not refer to center of cell. According to taken assumptions, the shortest possible path is obtained by seeking and evaluating different information contained in every cell. Trajectories will be smoother if the cell is related to proper size. The future research can consider cases with flight paths composed of curves not crossing centers of the cells as well.

The entire FRA considered in the overview is closed inside blue boundaries and has been described by vector A. Vector A defines state of airspace: it contains 34 cells labelled by $\mathrm{X}$. Every $\mathrm{X}$ has assigned individual number among 34-element set. Each data structure $X_{i}$ includes components $a_{1}, a_{2}, a_{3}, \ldots, a_{n}$. Single record $\boldsymbol{a}$ contains certain information about airspace that has been described in chapter 3.1 (Tab. 1). Each record $a$ is equivalent to air operation usability properly to determined criteria. Assuming that the flight path will be performed via the square-cells centers the mathematical notation of that example looks in the following way:

$$
\mathrm{A}=\left[\begin{array}{c}
X_{1} \\
\ldots \\
X_{34}
\end{array}\right]
$$

where: $\mathrm{X}$ - airspace cells that have been checked to select path.

$\mathrm{X}$ gathered into numerous different series creates possible routes on a linked way between entry and exit FRA points. Example of two single cells located on potential flight path has been presented in Tab. 2 . 


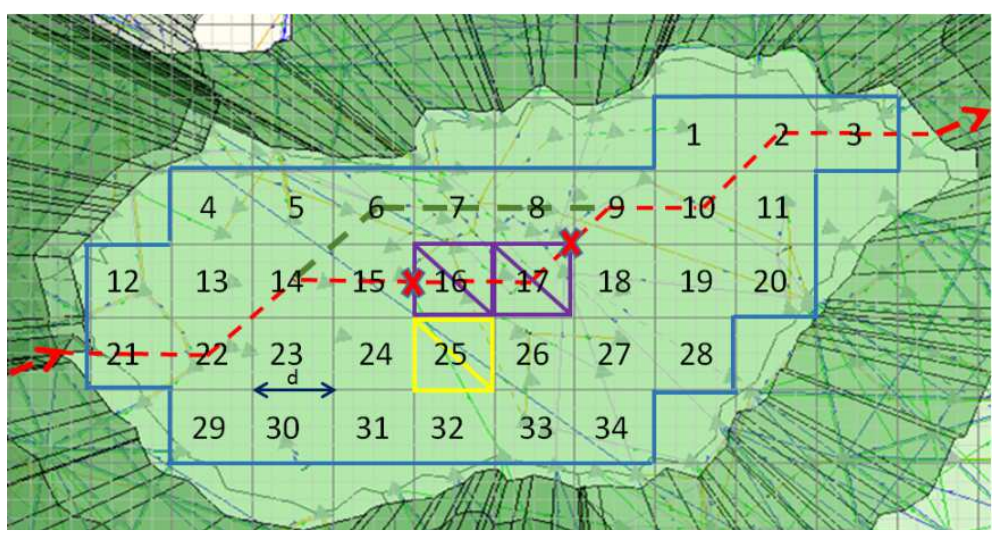

Fig. 6. The route planning in FRA example, 2D view

The assumption is that the shortest possible path (red trajectory in Fig. 6) via cells $16^{\text {th }}$ and $17^{\text {th }}$ (violet boundary) cannot be performed due to military operation with regard to time gap (Tab. $2 X_{16}, a_{5}$ ). Then the system seeks different path that is as short as possible. The current system assumes that network-nodes are located exactly in the cells center. Every cell is connected to contiguous cells via distance equivalent to single cell's edge. The distance between two contiguous cells in diagonal configuration is equivalent to length of one single cell's edge

Table 2. An example of vector interpretation

\begin{tabular}{|c|c|c|}
\hline & \multicolumn{2}{|c|}{ Description of vector's interpretation } \\
\hline $\mathrm{X}$ & $X_{6}$ & $X_{16}$ \\
\hline$a_{1}$ & [6] & {$[16]$} \\
\hline$a_{2}$ & {$[0,0,7,16,15,14,5,0]$} & {$[7,8,17,26,25,24,15,6]$} \\
\hline$a_{3}$ & $\begin{array}{c}{[0,0,0, d, d \sqrt{2}, d, d \sqrt{2}, d]} \\
d-\text { length of the square's edge (Fig. } 6 \text { ) }\end{array}$ & $\begin{array}{r}{[d, d \sqrt{2}, d, d \sqrt{2}, d, d \sqrt{2}, d, d \sqrt{2}]} \\
d-\text { length of the square's edge (Fig. } 6 \text { ) }\end{array}$ \\
\hline$a_{4}$ & {$[18.583,47.569]$} & {$[19.373,47.247]$} \\
\hline$a_{5}$ & {$[1,1, \mathbf{1}, 1,1,1,1,1,1,1]$} & $\begin{array}{l}\qquad 1,1, \mathbf{0}, 0,0,0,0,0,1,1] \\
\text { note: } 3^{\text {rd }} \text { element indicates airspace availa- } \\
\text { bility in scheduled enter into airspace. For } \\
\text { that reason, airspace user has possibility to } \\
\text { consider flight plan one or more times be- } \\
\text { fore the interval }\end{array}$ \\
\hline$a_{6}$ & {$[180,2]$} & {$[315,5]$} \\
\hline$a_{7}$ & $\begin{array}{c}{[4 / 40,8 / 40,12 / 40, \underline{35 / 40,39 / 40,37 / 40}} \\
19 / 40,12 / 40,11 / 40,5 / 40]\end{array}$ & $\begin{array}{l}\quad[4 / 40,8 / 40,0 / 0,0 / 0,0 / 0,39 / 40,35 / 40, \\
\qquad 29 / 40,12 / 40,5 / 40] * \\
\text { * when the adverse weather conditions ap- } \\
\text { pears, the cell has be described in way to } \\
\text { avoid aircrafts occurrence that time, i.e. as- } \\
\text { signed } 0 \text { volume rate }\end{array}$ \\
\hline
\end{tabular}


multiplicities by $\sqrt{2}$. Alternative trajectory would be appointed via cell $23^{\text {th }}-26^{\text {th }}$ and 18th cell, however adverse weather conditions (inside cell number $25^{\text {th }}$ ) makes that airspace inoperable. Bypassing the $25^{\text {th }}$ cell, the path would be appointed via $32^{\text {nd }}$ cell, however it takes long additionally forced distance. Seeking next cells to perform, the route via cells $6^{\text {th }}, 7^{\text {th }}$ and $8^{\text {th }}$, is considered and indicates perspectives to obtain an alternative that is as short as possible. Identically, every remaining possible cell has to be checked in the same way. Evaluating path that captures data from cells should be executed until information about possible alternatives are exhausted. Then comparison between variants will reveal a satisfactorily flight path. That picture presents flight route planning system in a created airspace model that is the subject of the article. Since airspace user can re-enter operational time, the alternative path before or after military action or adverse weather conditions would be assigned. Operational time in ATM is quite an important factor because time affects subsequent flights. Moreover, since cells $16^{\text {th }}$ and $17^{\text {th }}$ are closed, that state implies searching alternative routes. It is obvious if some part of the space is closed/excluded form operation air density of air traffic in surrounding areas rises.

The final objective of the airspace model and algorithm notion is to extract optimal flight plan due to airspace availability and user's demands. The system evaluates and displays alternatives for flight plan following the data inserted inside cells. Although flight plan will be displayed respectable due to optimization method, it has been assumed that the possibility to change individual criteria exists. The airspace user will receive confirmed flight plan necessary for certain operation data.

\section{Conclusions}

The airspace model notion presented in the article should make flight planning process more transparent to airspace users. Currently, users have to precisely overview situation and environmental conditions on a planned route before the flight. However, efforts undertaken towards flight planning do not guarantee that the desired path will be accepted. Airspace user, thanks to the commonly introduced automatic flight plan algorithm, that uses airspace model described in the article, shall obtain a few path alternatives after fulfilling departure and arrival places in the intend time. The complex system, that is set and interacts with different data, will automatically check environment and airspace availability. Then, from among a few different paths that users receive, there will be a possibility to select the most proper path to user's preferences. When a path is being accepted, the user will obtain confirmation [8].

The concept requires to construct a robust algorithm which will provide operational safety combined with efficiency. Full implementation of FRA is quite a difficult process. In consequence many countries still uses ATS network routes 
mainly starting experiments with FRA in nighttime only. FRA demands to implement a reliable system which would handle with enormous traffic perfectly. The 2D airspace model described in this article shows how facilitations for airspace users can improve the flight planning process. The further developed algorithm will select data from airspace model's cells to lead a flight via certain graph vertexes $[5,10]$. Further researches need to be examined in a 3D space model. It is significant to examine the situation when a huge number of flight plans are set at the same time via the same cell.

\section{References}

[1] Baumgartner M., Finger M.: The Single European Sky gridlock: A difficult 10 year reform process, Utilities Policy, 31 (2014) 289-301.

[2] Das D., Sharma S., Parti R., Singh J.: Analyzing the effect of aviation infrastructure over aviation fuel consumption reduction, J. Air Transport Manag., 57 (2016) $89-100$.

[3] Kopecki G., Pęczkowski M., Rogalski T.: Przykładowy algorytm automatycznego wyznaczania trasy przelotu w przestrzeni lotów swobodnych, Autobusy, 18 (2017) 1219-1224.

[4] Schaefer D., Castelli L., Cook A.: Long-term and innovative research in ATM, J. Air Transport Manag., 56 (2016) 2016.06.002.

[5] Tomczyk G., Rogalski T., Bakunowicz J.: Koncepcja przygotowania i koordynacji planów lotów IFR w obszarze lotów swobodnych, Autobusy, 17 (2016) 707-713.

[6] Sergeeva M., Delahaye D., Mancel C., Vidosavljevic A.: Dynamic airspace configuration by genetic algorithm, J. Traffic Transp. Eng., 4 (2017) 300-314.

[7] SESAR2020. Solutions for the Future Air Traffic Management System, Brussels 2017.

[8] SESAR Joint Undertaking, European ATM Master Plan. Executive View, Luxembourg 2015.

[9] Steen M.: Graph Theory and Complex Networks: An Introduction, ISBN 978-90815406-1-2, Paperback, 2010.

[10] Trudeau R.: Introduction to Graph Theory, Dover Publications Inc., New York 1996.

\section{MODEL PRZESTRZENI POWIETRZNEJ UMOŻLIWIAJĄCY AUTOMATYCZNE PLANOWANIE LOTU WE FREE ROUTE AIRSPACE}

\section{Streszczenie}

Artykuł przedstawia koncepcję zamodelowanej przestrzeni powietrznej w sposób umożliwiający automatyczne planowanie lotu w Przestrzeni Lotów Swobodnych (Free Route Airspace FRA). Zaprezentowany model usprawnia czynności składania planu lotu przez użytkownika, jednocześnie gwarantując bezpieczną separację statków powietrznych. Tematyka artykułu jest związana z badaniami do projektu Jednolitej Europejskiej Przestrzeni Powietrznej (Single European ATM Research - SESAR), której podstawowe założenie stanowi poprawa efektywności i bezpieczeństwa operacji w transporcie lotniczym. Efektywniejsze Zarządzanie Ruchem Lotniczym (Air 
Traffic Management - ATM) jest możliwe przez wprowadzenie koncepcji Elastycznego Zarządzania Przestrzenią Powietrzną (Flexible Use of Airspace - FUA). Elastyczne Zarządzanie Przestrzenią Powietrzną pozwala na monitorowanie dostępności przestrzeni w różnych odstępach czasowych, w sposób umożliwiający uwzględnienie planowanego natężenia ruchu wobec innych warunków, np. atmosferycznych.

Przedstawiony w artykule opis przestrzeni powietrznej opiera się na opisie matematycznym. Przyjęte zostało założenie, że cała przestrzeń powietrzna składa się z jednakowej wielkości kwadratów (lub sześcianów w przypadku przestrzeni 3D). Każdy kwadrat lub sześcian ma przydzieloną pojemność wraz z wartościami określającymi dostępność w ustalonym czasie. Dostępność jest uwarunkowana przez wiele czynników, np. zagęszczenie ruchu lotniczego. Wykonane badania wskazują, że zamodelowana w ten sposób przestrzeń powietrzna stwarza potencjał do planowania lotu. W konsekwencji wprowadzenia przez użytkownika dwóch punktów lotu - początkowego i końcowego, przeszukana w następstwie przestrzeń pozwala na przeanalizowanie i zaproponowanie przez system trasy według przyjętego kryterium.

Słowa kluczowe: transport, nawigacja, transport lotniczy, planowanie lotu, bezpieczeństwo lotnicze

DOI: $10.7862 / \mathrm{rm} .2018 .01$

Otrzymano/received: 5.01 .2018

Zaakceptowano/accepted: 8.03.2018 